\title{
Past and present: Improving early childhood visual spatial abilities through traditional game cengkling
}

\author{
Nofrans Eka Saputra, Yun Nina Ekawati \\ Department of Psychology, Universitas Jambi, Indonesia \\ Corresponding author: nofransekasaputra@unja.ac.id
}

\section{ARTICLE INFO}

Article history

Received June 1, 2020

Revised December 21, 2020

Accepted February 26, 2021

Keywords

cengkling;

early childhood;

traditional game;

visual spatial abilities.

\begin{abstract}
Visual spatial abilities are essential in academic and everyday life. This study aimed to determine the impact of traditional game cengkling on early childhood visual spatial abilities. A quasiexperimental with pretest-posttest control group design was applied with 18 participants evenly divided into experimental and control groups. Participants in the experiment group were given traditional game cengkling with a modification on the visual spatial system such as visual perception, color perception, and space. A visual ability scale was used to collect the data both in pretest and posttest. Data were then analyzed with the independent sample t-test and the paired sample t-test. The results show a significant difference in visual spatial abilities on pretest and posttest scores in the experimental group. Whereas in the control group, no significant difference in visual spatial abilities was found. It can be concluded that the traditional game cengkling stimulates visual spatial abilities in early childhood.
\end{abstract}

\section{Introduction}

Pandemic covid-19 started at the end of 2019 in China, spread to all countries in the world impacted in all aspects of human life, including education. Distance learning has become a solution to maintain education for students (Tadesse \& Muluye, 2020). In distance learning, the role of parents is more complex, especially for early childhood education. Parents' involvement is needed to conduct learning at home, supervise the learning process, and even more assess the learning outcome designed by the teacher (Solekhah, 2020). Therefore, the Government of Indonesia developed various forms of online learning focus on communication between teachers, students, and parents using unsophisticated equipment. When conducting the learning process at home, parents may use any equipment to stimulate their abilities, including visual spatial abilities.

Visual spatial abilities are essential for children. Visual spatial abilities are an essential predictor in STEM (Science, Technology, Engineer and Math) achievement and career (Uttal \& Cohen, 2012; Uttal et al., 2013). Individuals with visual spatial abilities will succeed in engineering and physical disciplines such as architecture, physics, chemistry, dentistry, medicine, and medical surgery in the future (Wai, Lubinski, \& Benbow, 2009). Furthermore, visual spatial proficiency is also related to remarkable victories in several fields, including trade such as craftsmen, positions in specific industries, surveyors, drafters, map makers (Shea, Lubinski, \& Benbow, 2001), and musicians (Hetland, 2000). Therefore every child is expected to have visual spatial abilities to welcome the industrial revolution 4.0, which required technological proficiency (Ekawati \& Saputra, 2019). 
Visual spatial abilities are expected to be stimulated early childhood as the logical spatial brain structure fully functions within childhood (Gersmehl \& Gersmehl, 2007). Spatial skill in early childhood has been a stronger predictor than numeral ability within first and second grades (Gunderson, Ramirez, Beilock, \& Levine, 2012). Moreover, visual spatial activities during childhood will enhance visual spatial abilities in adulthood (Doyle, Voyer, $\&$ Cherney, 2012). Activities in sport, play, artistic, and technological that involved reasoning of space quality, mental visualization, and observing physical objects are categorized as visual spatial activities (Peterson, Weinberger, Uttal, Kolvoord, \& Green, 2020).

Play is a learning method for children. The integration a play activity thorugh a game in the learning proces is known as games-based learning (Trajkovik, Malinovski, VasilevaStojanovska, \& Vasileva, 2018). The traditional game is an alternative of games to be used in the learning process. The previous study among elementary students in Macedonia found that traditional games' implementation increases students' learning outcomes (Trajkovik et al., 2018). While a study among elementary students in Indonesia shows, traditional games are effective mediums to enhance students delf control (Iswinarti, 2020). The traditional game is a folk story from society inherited from one generation to the next generation and played by using particular tools. In the past, traditional games become a community entertainment to stay relaxed and create joy after working in the rice field or other community work (Basri et al., 2018).

Cengkling is one of traditional game of Jambi. Cengkling has known in many different names in several regions of Indonesia including englek (Java), asinan, gala asin (Kalimantan), intingan (Sampit), tengger-tengger (Gorontalo), cak lingking (Bangka), dengkleng, teprok (Bali), gili-gili (Merauke), deprok (Betawi), engklek (Pacitan), sonda (Mojokerto), and tepok gunung (Jawa Barat) (Iswinarti, 2020). The previous qualitative study found community in Jambi believes cengkling is one of the traditional games that may increase various abilities, including children's visual spatial abilities (Saputra \& Ekawati, 2017).

Ekawati \& Saputra (2019) then modified traditional cengkling by creating various colorful geometry shapes, such as triangle, hexagonal, pentagonal, parallelogram, rectangle, oval, and trapezoid from the initial shapes, that are square and circle. Cengkling also adapts the labyrinth and block puzzle game to stimulate the children to jumps in various directions or positions, such as a twisting maze. Block puzzle stimulates children's skills in match images, including adjusting or classify colors, shapes, and positions. By gaining the skills, children's understanding of visual spatial concepts will be enhanced (Levine, Ratliff, Huttenlocher, \& Cannon, 2012). Moreover, cengkling traditional game uses scaffolding or mediating learning approach. Thus the children can be helped to remember activities in the game. Scaffolding is expected to support an independent study that parents, teachers, or the nanny can apply to support children's visual spatial acquirement when they do the exploration (Newcombe \& Frick, 2010).

As a follow-up of the previous studies (Ekawati \& Saputra, 2019; Saputra \& Ekawati, 2017), this study explores the traditional game's effect cengkling to enhance visual spatial abilities among early childhood. This study hypothesis that traditional games cengkling will increase visual spatial abilities in early childhood.

\section{Method}

\section{Research Design}

Quasi-experiment research with pretest-posttest control group design is applied in this study. The experiment and control group are decided non-randomly. Table 1 shows the quasiexperiment design. 
Table 1

Research Design

\begin{tabular}{llll}
\hline Group & Pretest & Treatment & Posttest \\
\hline EG & O1 & X & O2 \\
CG & O1 & - & O2 \\
\hline
\end{tabular}

Description:

$\mathrm{EG}=$ Experiment Group

$\mathrm{CG}=$ Control Group

$\mathrm{O} 1=$ Pretest

$\mathrm{O} 2=$ Posttest

$\mathrm{X}=$ Cengkling Traditional Game Treatment

First, a pretest was conducted to obtain participants' visual spatial scores by delivering visual spatial scale to the experiment and control groups. The pretest was carried out before participants in the experiment group were given the cengkling traditional game treatment. Second, a cengkling traditional game was only given to the experiment group, while the control group was not given. In the treatment stage, the participants were asked to play cengkling for three sessions within three subsequent days, with around 45 minutes for every session. A facilitator and two co-facilitators were involved in the treatment stage. Figure 1 shows the three sessions on cengkling traditional game treatment. Third, a posttest was conducted after the treatment by measuring participants' visual spatial scores in both the experiment and control groups.

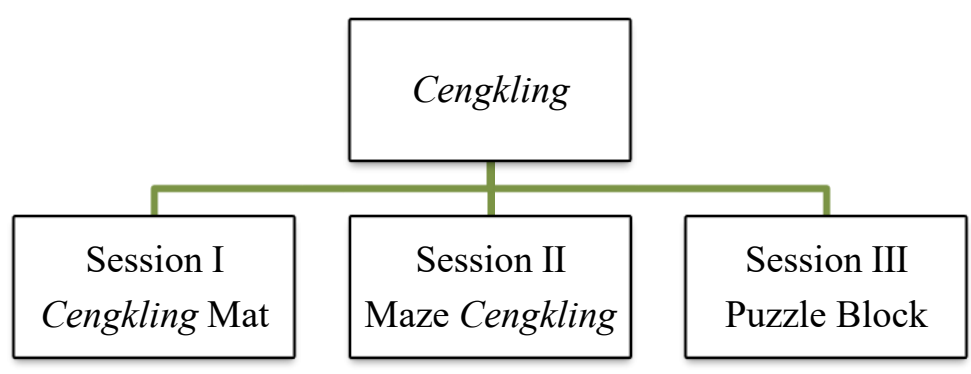

Figure 1. Sessions of cengkling traditional game

\section{Participants}

Eighteen early childhood students aging from $4-6$ years old participated in this study. The majority of participants are 5 years old $(55.56 \%)$ and female $(61.1 \%)$. The participants were divided into experimental and control groups, with an equal number, nine students in each group.

\section{Instrument}

In this study, a spatial visual abilities scale was developed base on spatial visual components, including the ability to perceive color, shape, and space, ability to perceive visually (space, shape, and color concept), ability to transform space shape captured by the eye to another form (Yaumi \& Ibrahim, 2013). The scale consists of 30 items, as shown in Table 2. 
Table 2

\begin{tabular}{|c|c|c|}
\hline Component & Indicator & Item \\
\hline \multirow[t]{2}{*}{$\begin{array}{l}\text { Visual } \\
\text { Perception }\end{array}$} & $\begin{array}{l}\text { Scratching, drawing, and coloring something with } \\
\text { color according to the real form }\end{array}$ & $4,5,6^{*}$ \\
\hline & Arranging building such as puzzle and block & $30,28 *$ \\
\hline \multirow[t]{5}{*}{ Visual Spatial } & Knowing various kind of colors ( 12 colors) & 1,2 \\
\hline & $\begin{array}{l}\text { Classifying things or pictures according to the color } \\
\text { and shape series }\end{array}$ & $3,17,18$ \\
\hline & Indentifying form of space & $7 *, 8 *, 9,10^{*}, 11,12,13^{*}, 14^{*}, 15$ \\
\hline & Understanding all concept of direction and position & $19,20,21,22,23$ \\
\hline & Understanding the concept of size & $24 *, 25,26,27$ \\
\hline \multirow[t]{2}{*}{ Transform } & $\begin{array}{l}\text { Switching the real shape (3D) to picture (2D) and vice } \\
\text { versa }\end{array}$ & 16,29 \\
\hline & Total Item & 30 \\
\hline
\end{tabular}

Note: $*=$ Excluded Items

A try-out was conducted by distributing the visual spatial abilities scale to nine kindergarten students. The item discrimination index with the value of .300 is considered satisfying (accepted) (Azwar, 2018). However, in this study, only item with item discrimination index $\geq .500$ will be included in the final measurement tool as the number of items required for each component are met. The final visual spatial scale consists of 22 items, with an item discrimination index ranging from .519 to .816 and the reliability coefficient value .952 . Table 3 shows the sample of the visual spatial abilities scale items.

Table 3

Spatial Visual Abilities Scale

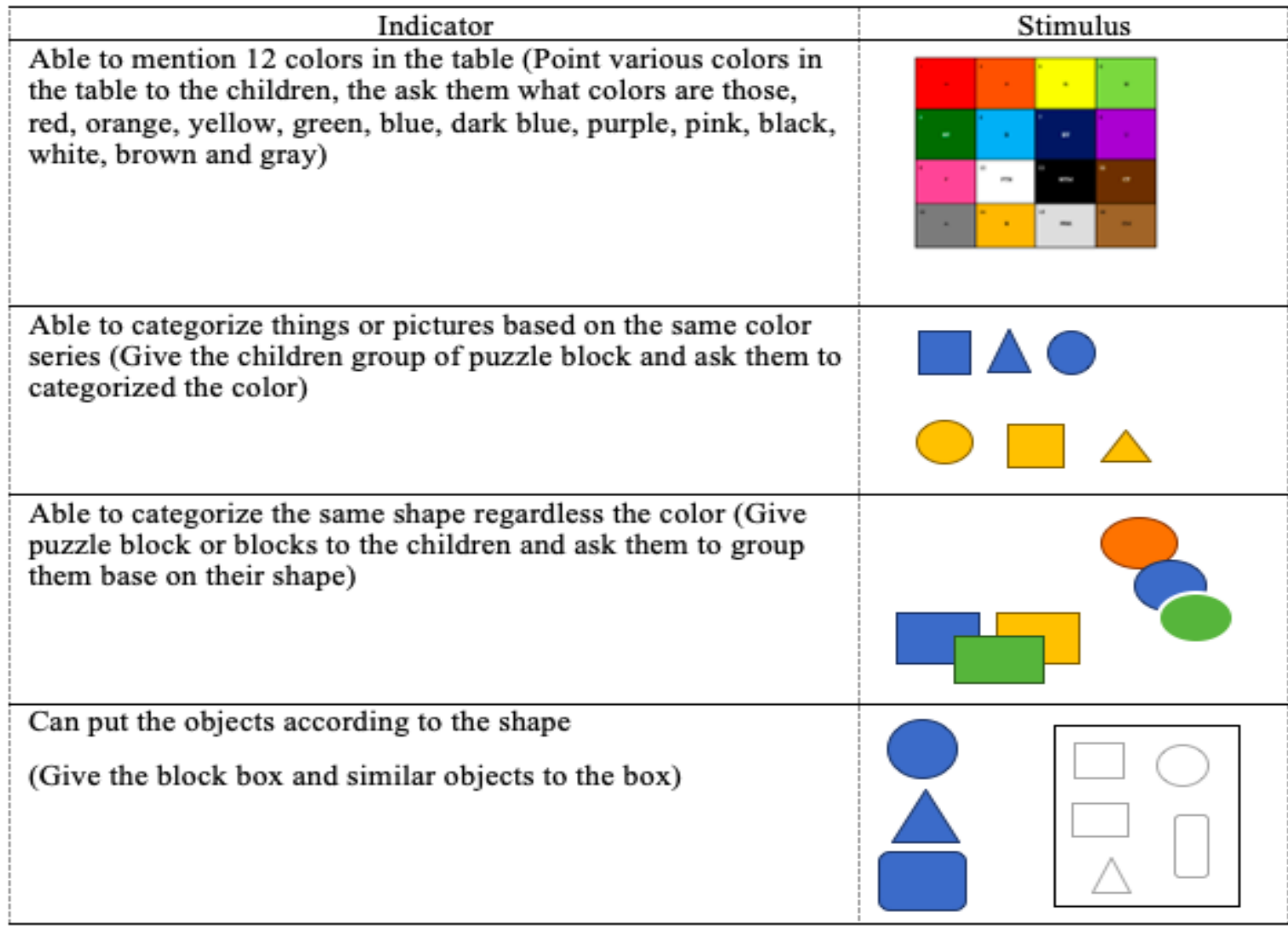




\section{Cengkling Traditional Game Module}

The cengkling traditional game used in the research is shown in Figure 2. The game consists of a cengkling mat, cengkling maze mats, and kuju that modified from previous research (Iswinarti, 2020; Pradnyawati, Antara, \& Ujianti, 2017; Rosidah, 2014), and also a puzzle block that has been modified from previous studies (Hastuti \& Santia, 2019; Jirout \& Newcombe, 2015). The modification was conducted on the geometry shapes, color series, and track showing their direction and position. This modification is expected to be a stimulus in encouraging the development of visual spatial abilities in early childhood.

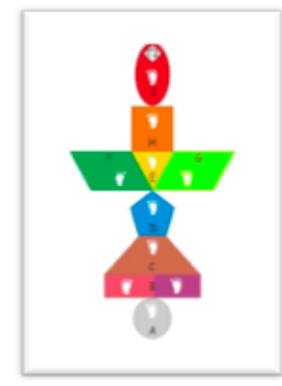

Cengkling

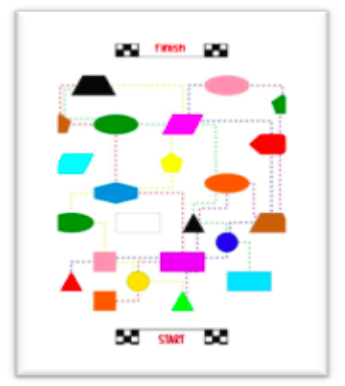

Maze Cengkling

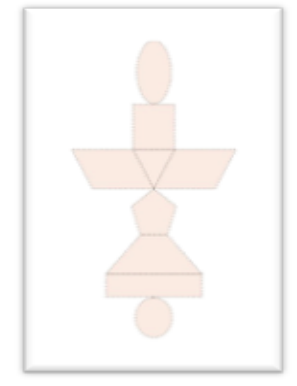

Puzzle Blok

Figure 2. Cengkling traditional game

Source: Ekawati \& Saputra (2019)

The cengkling game introduces children to various colors and to be able to recognize the shape of space. Tools in the cengkling game are cengkling mat and kuju. In the cengkling game, the children are divided into several groups. Each child in the group plays the cengkling in turn. The children pass through the squares filled with colors and shapes from the first square to the last, grabbing by throwing stones or kuju.

The maze cengkling strengthens understanding of space's shape and understands all the concepts of direction, position, and size. The maze cengkling mat consists of several grooves, and the child must pass it according to the order in the challenge card that has been made. The child goes through each of the building blocks according to the sequence, such as turning roads in each sequence. If they do not follow the path, they will meet an empty plot or take the wrong path. Children also pass the shapes by mentioning the shapes' names and their directions/positions, and the colors.

Puzzle block trains children to compose a series of cengkling that have been played by themselves. The puzzle block also strengthens their understanding of all concepts in remembering colors, shapes, concepts of direction and position, size, and changing the eye catches' shape and knowing the various colors. Other than puzzle block, paper and crayons are also used in this game. Children play in groups. The child arranges the shapes of the cengkling using a puzzle of the same color and shape in the picture.

The research module has been validated by four validators who are considered professional in their field by the researcher, including teachers, parents, psychologists, and cultural figures (Ekawati \& Saputra, 2019). The validators assessed three visual spatial components: shape perception (color and space), visual perception, and space transformation by giving a rating from 1 (very inappropriate) to 5 (very suitable). Content validity was determined with Aiken V based on the score gained from the validators. Each validator Table 4 shows the Aiken $\mathrm{V}$ of each subsection of the cengkling traditional game module. All subsections have Aiken more than .50 indicate that the module has good content validity (Azwar, 2018). The validation results show cengkling traditional game module has moderate 
to high validity in every visual spatial subsection. The results indicate traditional game cengkling module meets the content validity.

Table 4

Content Validity

\begin{tabular}{ll}
\hline Subsection Module & Aiken V \\
\hline 1.1 & .55 \\
1.2 & .65 \\
1.3 & .65 \\
2.1 & .55 \\
2.2 & .55 \\
3.1 & .55 \\
3.2 & .55 \\
3.3 & .65 \\
\hline
\end{tabular}

\section{Data Analysis}

The independent sample t-test and the paired t-test sample were applied to test the research hypothesis with SPSS 16 program. The paired sample test was used to test the differences between pretest and posttest scores either in the experimental or control group. In comparison, the independent sample t-test was used to test the difference of pretest score between experimental and control groups and posttest score between experimental and control groups.

\section{Results}

Descriptive statistics, including mean and standard deviation of pretest and posttest scores in the experiment and control group, are shown in Table 5.

Table 5

Descriptive Statistic

\begin{tabular}{cccc}
\hline Group & Score & Mean & Standard Deviation \\
\hline Experiment & Pretest & 74.11 & 8.7 \\
& Posttest & 87.33 & 5.8 \\
Control & Pretest & 58.00 & 23.4 \\
& Posttest & 55.00 & 22.1 \\
\hline
\end{tabular}

Figure 3 shows the different mean scores of the pretest-posttest of the experiment group compared to that of the control group. An increasing mean score of pretest to posttest was found in the experiment group. While in the control group, the mean score of the posttest is slightly declining compared to the pretest. 


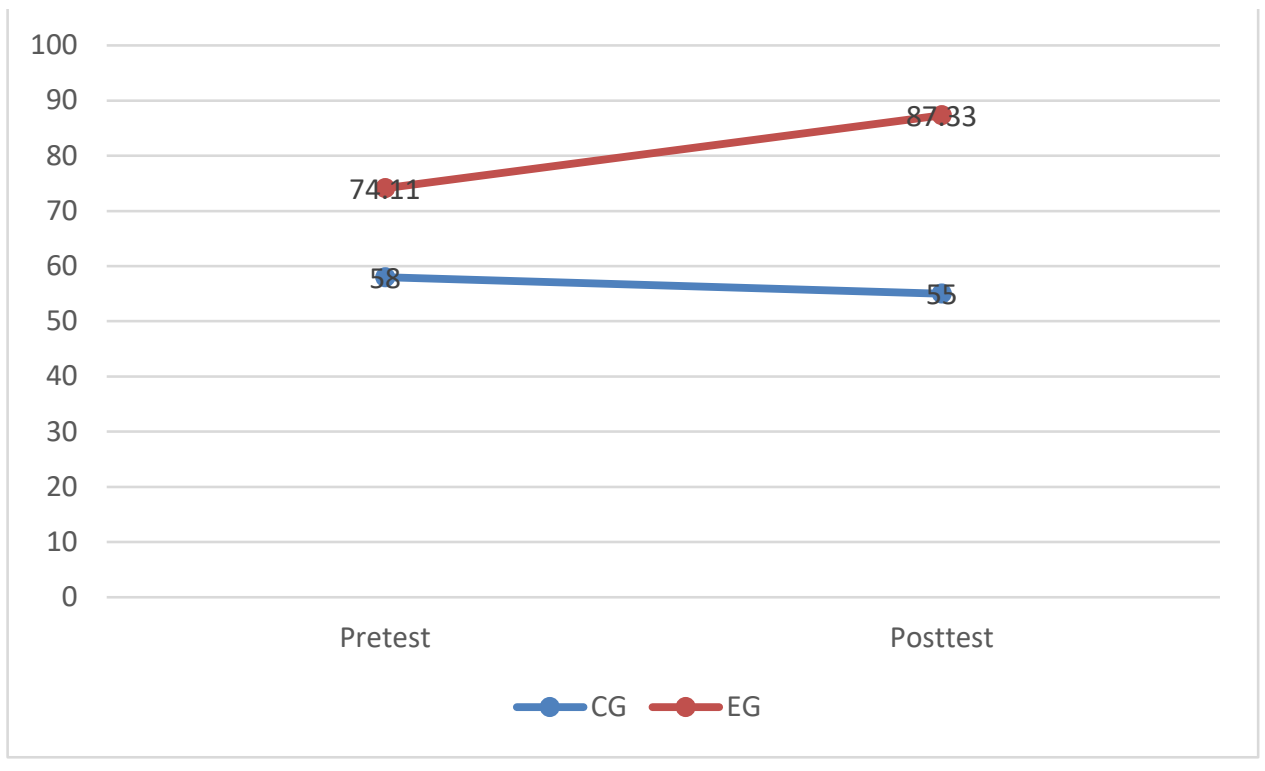

Figure 3. The difference in the mean score of experiment and control groups

Table 6 shows the result of the data analysis. Based on paired sample t-test, there is a significant difference between pretest and posttest scores among participants in the experiment group. This result indicates the mean score of the posttest is higher than the mean score of the pretest. Therefore, in the experiment group, the participants' visual spatial abilities increase after they were given treatment, that is, playing traditional games cengkling. On the contrary, there is no significant difference between the pretest and posttest among control groups. This result means that the participants' visual spatial abilities remain the same in the control group even though there is a slightly decreased score.

Based on the independent sample t-test, there is no different mean score of pretest between the experiment and control groups. This result indicates that the two groups' participants' spatial ability was not different before participants in the experiment group were given traditional games cengkling. Moreover, the mean score of the posttest between participants in the experiment and control group was significantly different. The mean score of the posttest among participants in the experiment group is higher than the mean score of the posttest among the control group participants.

Table 6

Results of the t-test

\begin{tabular}{llcc}
\hline \multicolumn{1}{c}{ t-test } & \multicolumn{1}{c}{ Variable } & t value & Exact Sig (2-tailed) \\
\hline \multirow{2}{*}{ Paired sample $t$-test } & Pretest EG dan Posttest EG & -8.420 & .000 \\
& Pretest CG dan Postest CG & 2.233 & .056 \\
\multirow{2}{*}{ Independent sample $t$-test } & Pretest EG dan Pretest CG & 1.540 & .162 \\
& Posttest EG dan Posttest CG & 3.628 & .007 \\
\hline
\end{tabular}

\section{Discussion}

This research results show the traditional game cengkling enhances the visual spatial abilities of students in early childhood. The cengkling game was modified to stimulate early childhood to develop visual spatial abilities. This game has been modified into various shapes, for example, from only circle and square to triangle and rectangle (Iswinarti, 2020). However, in 
this study, traditional game cengkling has been modified into triangle, hexagon, pentagon and completed with different colors in each shape.

The traditional game cengkling in this study also modifies maze games (Rosidah, 2014) and puzzle blocks (Hastuti \& Santia, 2019; Jirout \& Newcombe, 2015; Levine et al., 2012). Hence, the traditional game cengkling also stimulates children to jump in different directions and positions, such as the winding maze. While puzzle block stimulates children to have matching pictures skill (arranging or classifying color, shape, and position), thus strengthen the understanding of the visual spatial concept of early childhood (Levine et al., 2012).

The traditional game cengkling stimulates early childhood to understand and remember the color and figure out geometry shapes. The traditional game cengkling has been modified into geometric shapes such as hexagon, pentagon, triangle, circle, rectangle, and square. The shapes were also colored with primary color, therefore stimulating early childhood to differentiate every color and shape. During the treatment sessions, the participants understood direction, including left and right, back and front, and identify the color, geometry in the puzzle block game.

This study's results align with previous research findings (Hastuti \& Santia, 2019; Jirout \& Newcombe, 2015; Levine et al., 2012; Pradnyawati et al., 2017). The stimuli used in previous research, such as block puzzles and other game tools, can improve children's visual spatial abilities. However, this study uses local wisdom not carried out by other research, namely the modified game of clove in geometry, which has color serialization, increasing the visual spatial abilities of early childhood relevance with sophisticated scientific engineering. Hence, enhancing early childhood visual spatial abilities will also prepare them to be better in engineering and STEM (Science, Technology, Engineering, and Math) (Uttal \& Cohen, 2012; Uttal et al., 2013).

Moreover, the traditional game cengkling may be applied as an alternative learning activity at home during the pandemic covid 19. Through this traditional game cengkling, early childhood may gain knowledge from play activities directly with parents and adults' support. The presence of adult as an educator support the acquirement of visual spatial abilities among early childhood (Newcombe \& Frick, 2010) when they play traditional game. Adult intervention can increase early childhood to use and represent visual spatial abilities that will be more beneficial to their learning process (Gersmehl \& Gersmehl, 2007).

This study has some limitations. It is, first, related to the measurement tool. The visual spatial abilities scale is expected to be revised. Although the scale is reliable, further research is needed in terms of construct validity analysis. Second, the pretest-posttest design only concerns the score of visual spatial abilities before and after treatment that is play traditional game cengkling. Multiple assessments in each session may be applied to monitor the increasing score of visual spatial abilities from a session to the next session. Third intelligence, which theoretically influences visual spatial abilities (Kotsopoulos, Makosz, Zambrzycka, \& Dickson, 2019), is not be controlled. Further research may involve intelligence as a controlled variable.

\section{Conclusion}

Cengkling traditional game has been modified to develop visual spatial abilities among students in early childhood. Perceive ability on color, shape, and space; visually perceive ability on space, shape, and color; and space transformation ability captured by the eyes to other forms are visual spatial abilities increasing in this study. The participants' experience of differentiating direction left-right, front-back, and figure out colors increases by applying geometry in the cengkling game, maze, and puzzle block. Therefore, traditional game cengkling is an alternative to enhance the visual spatial abilities of early childhood. 


\section{References}

Azwar, S. (2018). Metode penelitian psikologi (Research method in psychology) (Edisi II). Pustaka Pelajar.

Basri, L. O. A., Momo, A. H., Marhadi, A., Rahman, A., Jers, L. O. T., Aslim, A., \& Aswati, A. (2018). The unsustainability of kalego traditional game among Muna community of Watopute district. Asian Social Science, 14(2), 12-17. https://doi.org/10.5539/ass.v14n2p12

Doyle, R. A., Voyer, D., \& Cherney, I. D. (2012). The relation between children spatial activities and spatial abilities in adulthood. Journal of Applied Developmental Psychology, 33(2), 112-120.

Ekawati, Y. N., \& Saputra, N. E. (2019). Uji coba modul paket alat permainan edukatif (APE) cengkling/ engklek untuk meningkatkan kemampuan visual spasial anak (Try out educational game cengkling/engklek module to increase children's visual spatial abilities). Temilnas $\quad X I \quad I P P I, \quad$ 727-739. http://psychologyforum.umm.ac.id/files/file/Prosiding IPPI 2019/76_ Naskah 727739.pdf

Gersmehl, P. J., \& Gersmehl, C. A. (2007). Spatial thinking by young children: Neurologic evidence for early development and "educability". Journal of Geography, 106(5), 181191. https://doi.org/10.1080/00221340701809108

Gunderson, E. A., Ramirez, G., Beilock, S. L., \& Levine, S. C. (2012). The relation between spatial skill and early number knowledge: The role of the linear number line. Developmental Psychology, 48(5), 1229-1241. https://doi.org/10.1037/a0027433

Hastuti, D., \& Santia, A. (2019). Pengaruh permainan building block terhadap kecerdasan visual anak di TK Ulil Albab Kota Bandung (The influence of building block game on children's visual intelligence in Ulil Albab Kindergarten Bandung city). Jurnal Obsesi, 2(1), 70-75. https://doi.org/10.31004/obsesi.v2i1.9

Hetland, L. (2000). Learning to make music enhances spatial reasoning. Journal of Aesthetic Education, 34(3/4), 179-238. https://doi.org/10.2307/3333643

Iswinarti. (2020). Traditional games engklek as a medium to increase self-control in schoolaged children in Indonesia. Journal of Research and Innovation in Social Science (IJRISS), IV(VIII), 676-682.

Jirout, J. J., \& Newcombe, N. S. (2015). Building blocks for developing spatial skills: Evidence from a large, representative U.S. sample. Psychological Science, 26(3), 302310. https://doi.org/10.1177/0956797614563338

Kotsopoulos, D., Makosz, S., Zambrzycka, J., \& Dickson, B. A. (2019). Individual differences in young children's visual-spatial abilities. Early Child Development and Care, online first, 1-14. https://doi.org/10.1080/03004430.2019.1699918

Levine, S. C., Ratliff, K. R., Huttenlocher, J., \& Cannon, J. (2012). Early puzzle play: A predictor of preschoolers' spatial transformation skill. Developmental Psychology, 48(2), 530-542. https://doi.org/10.1037/a0025913

Newcombe, N. S., \& Frick, A. (2010). Early education for spatial intelligence: Why, what, and how. Mind, Brain, and Education, 4(3), 102-111. https://doi.org/10.1111/j.1751228X.2010.01089.x

Peterson, E. G., Weinberger, A. B., Uttal, D. H., Kolvoord, B., \& Green, A. E. (2020). Spatial activity participation in childhood and adolescence: Consistency and relations to spatial thinking in adolescence. Cognitive Research: Principles and Implications, 5, 43. https://doi.org/10.1186/s41235-020-00239-0

Pradnyawati, N. L. G., Antara, P. A., \& Ujianti, P. R. (2017). Pengaruh ragam hias geometri 
terhadap kecerdasan visual-spasial pada anak gugus V Kecamatan Kediri Kabupaten Tabanan (The influence of geometric decoration on visual-spatial intelligence in children of cluster V Kediri Tabanan District. Jurnal Pendidikan Anak Usia Dini Undiksha, 5(3), 295-304.

Rosidah, L. (2014). Peningkatan kecerdasan visual spasial anak usia dini melalui permainan maze (Enhancing children visual spatial abilities through maze game). Jurnal Pendidikan Usia Dini, 8(2), 281-290.

Saputra, N. E., \& Ekawati, Y. N. (2017). Permainan tradisional sebagai upaya meningkatkan kemampuan dasar anak (Tradisional games to increase children's basic abilities). Jurnal Psikologi Jambi, 2(2), 48-53.

Shea, D. L., Lubinski, D., \& Benbow, C. P. (2001). Importance of assessing spatial ability in intellectually talented young adolescents: A 20-year longitudinal study. Journal of Educational Psychology, 93(3), 604-614. https://doi.org/10.1037/0022-0663.93.3.604

Solekhah, H. (2020). Distance learning of Indonesian early childhood education (PAUD) during the covid-19 pandemic. International Journal of Emerging Issues in Early Childhood Education, 2(2), 105-115. https://doi.org/10.31098/ijeiece.v2i2.409

Tadesse, S., \& Muluye, W. (2020). The impact of COVID-19 pandemic on education system in developing countries: A review. Open Journal of Social Sciences, 08(10), 159-170. https://doi.org/10.4236/jss.2020.810011

Trajkovik, V., Malinovski, T., Vasileva-Stojanovska, T., \& Vasileva, M. (2018). Traditional games in elementary school: Relationships of student's personality traits, motivation and experience with learning outcomes. PLOS ONE, 13(8), e0202172. https://doi.org/10.1371/journal.pone.0202172

Uttal, D. H., \& Cohen, C. A. (2012). Spatial thinking and STEM education: When, Why, and How? Psychology of Learning and Motivation, 57(2012), 147-181. https://doi.org/10.1371/B978-0-12-394293-7.00004-2

Uttal, D. H., Meadow, N. G., Tipton, E., Hand, L. L., Alden, A. R., Warren, C., \& Newcombe, N. S. (2013). The malleability of spatial skills: A meta-analysis of training studies. Psychological Bulletin, 139(2), 352-402. https://doi.org/10.1037/a0028446

Wai, J., Lubinski, D., \& Benbow, C. P. (2009). Spatial ability for STEM domains: Aligning over 50 Years of cumulative psychological knowledge solidifies its importance. Journal of Educational Psychology, 101(4), 817-835. https://doi.org/10.1037/a0016127

Yaumi, M., \& Ibrahim, N. (2013). Pembelajaran berbasis kecerdasan jamak (Mulitiple intelligence based learning). Kencana. 